\title{
An experimental study of the effect of pressure on the formation of chromite deposits
}

\author{
NATASHIA DRAGE AND JAMES BRENAN \\ Dalhousie University \\ Presenting Author: natashia.drage@dal.ca
}

Despite extensive research on chromitites in the Bushveld Complex, the mechanism(s) that form such anomalous chromite segregations remains uncertain. Recent work applying the MELTS thermodynamic model proposed that reduction of pressure upon magma ascent shifts the silicate-in temperature to lower values, with the chromite-in temperature remaining unchanged, resulting in chromite-alone crystallization and formation of massive chromitites. We are evaluating this hypothesis through laboratory phase equilibrium experiments conducted at $0.1 \mathrm{MPa}$ and $1 \mathrm{GPa}$, employing two bulk compositions. Composition 1 (C1) corresponds to a widely accepted parental magma of Bushveld chromitites, termed B1. Composition $2(\mathrm{C} 2)$ is the same used in the MELTS modelling study, which contrasts with $\mathrm{C} 1$ most significantly in $\mathrm{Al}_{2} \mathrm{O}_{3}(17.4$ wt \% vs 11.8 wt $\%$ in $\mathrm{C} 1), \mathrm{MgO}$ (6.7 wt\% vs $11.9 \mathrm{wt} \%$ in $\mathrm{C} 1$ ), and $\mathrm{Cr}(680 \mu \mathrm{g} / \mathrm{g}$ vs $970 \mu \mathrm{g} / \mathrm{g}$ in $\mathrm{C} 1)$ contents. Thus far, experiments have been conducted at $0.1 \mathrm{MPa}$ by mounting synthetic starting materials on Fe-Ir alloy wire loops and equilibrating them over the temperature interval of $1170-1340^{\circ} \mathrm{C}$ in a vertical-tube, gas-mixing furnace for 24-48 hours, at the FMQ buffer. Results indicate that the $\mathrm{Cr} \#$ in $\mathrm{C} 1$ experimental chromite $(0.65-0.75)$ is within the range of the most primitive chromitites $(\sim 0.65-0.76)$ found in the Lower Critical Zone of the Bushveld Complex. The $\mathrm{Cr} \#$ of experimental chromite in $\mathrm{C} 2$ (0.6-0.62) is more consistent with chromitites in the Upper Critical Zone $(\sim 0.59-0.70)$. The $\mathrm{C} 1$ crystallization sequence agrees with that observed in the Lower Critical Zone with chromite + orthopyroxene on the liquidus at $1280^{\circ} \mathrm{C}$. Composition $\mathrm{C} 2$ crystallizes chromite-alone at $1280^{\circ} \mathrm{C}$, followed by plagioclase + chromite at $1200^{\circ} \mathrm{C}$ and plagioclase + chromite + orthopyroxene at $1170^{\circ} \mathrm{C}$, which is more reflective of the dominantly noritic Upper Critical Zone. MELTS modelling reproduces the observed phase assemblages and crystallization temperatures to within $10-30^{\circ} \mathrm{C}$, except that $\mathrm{C} 2$ chromite-alone crystallization begins at a higher temperature $\left(1280^{\circ} \mathrm{C}\right)$ than predicted $\left(1230^{\circ} \mathrm{C}\right)$. The $\mathrm{Cr}$ solubility modelled by MELTS is $\sim 20-50 \%$ and $\sim 70-85 \%$ higher at a given temperature than experimental values for $\mathrm{C} 1$ and $\mathrm{C} 2$ respectively. Experiments at $1 \mathrm{GPa}$ using $\mathrm{Fe}$-Ir capsules to buffer $\mathrm{fO}_{2}$ are in progress to document the chromite-in shift with pressure. 